\title{
IN-VIVO SAFETY AND EFFICACY EVALUATION OF A NOVEL POLYMERIC BASED LIDOCAINE FORMULATION FOR TOPICAL ANALGESIA
}

\author{
ANDREI LUCA ${ }^{1,9}$, COSMIN-TEODOR MIHAI $^{1}$, GABRIELA-DUMITRIȚA STANCIU ${ }^{1}$, \\ VERONICA BILD ${ }^{1,2}$, ELENA COJOCARU ${ }^{3}$, ROBERT ANCUCEANU ${ }^{4}$, VALERIA HARABAGIU ${ }^{5}$, \\ CRISTIAN PEPTU ${ }^{5}$, CATALINA ANIȘOARA PEPTU ${ }^{6}$, MAGDALENA-MARIA LEON- \\ CONSTANTIN $^{1,7} *$, TEODORA ALEXA-STRATULAT ${ }^{1,8}$
}

\author{
${ }^{I}$ CEMEX Laboratory, University of Medicine and Pharmacy ,, Gr. T. Popa”, 9-13 Mihail Kogălniceanu Street, Iași, Romania \\ ${ }^{2}$ Pharmacodynamics and Clinical Pharmacy Department, University of Medicine and Pharmacy ,, Gr. T. Popa”, 16 \\ Universităţii Str., 700115, Iași, Romania \\ ${ }^{3}$ Morphofunctional Sciences Department, Discipline of Pathology, University of Medicine and Pharmacy ,Gr. T. Popa”, 16 \\ Universității Str., 700115, Iași, Romania \\ ${ }^{4} A \& B$ Pharm Corp., Roman, Romania \\ 5 "Petru Poni” Institute of Macromolecular Chemistry, Aleea Grigore Ghica Voda 41A, 700487 Iași, Romania \\ ${ }^{6}$ Department of Natural and Synthetic Polymers, Faculty of Chemical Engineering and Environmental Protection, \\ „Gheorghe Asachi” Technical University of Iași, Dimitrie Mangeron Street, 73, 700050, Romania \\ ${ }^{7}$ First Medical Department, Discipline of Medical Semiology, University of Medicine and Pharmacy , Gr. T. Popa”, 16 \\ Universității Str., 700115, Iași, Romania \\ ${ }^{8}$ Medical Oncology-Radiotherapy Department, University of Medicine and Pharmacy „Gr. T. Popa”, 16 Universității Str., \\ 700115, Iași, Romania \\ ${ }^{9}$ Pneumology Department, University of Medicine and Pharmacy „, Gr. T. Popa”, 16 Universității Str., 700115, Iași, Romania
}

*corresponding author: leon.maria.magdalena@gmail.com

Manuscript received: May 2018

\begin{abstract}
Topical analgesics currently available still have efficacy, local tolerability and price issues. The aim of this study was to assess the efficacy of a new lidocaine-based spray (CX001) on experimental pain.Safety was assessed by histology examination of skin and liver tissue of CX001-treated mice. The effect of CX001 on nociceptive and inflammatory pain was assessed by periodic evaluation of the rat's response to thermal and mechanical stimuli and compared with EMLA $^{\odot}$ (reference topical analgesic).CX001-treated mice had no significant skin or liver modification. CX001's analgesic effect was superior to $\mathrm{EMLA}^{\mathcal{O}}$ in terms of response to mechanical stimuli in both the nociceptive and inflammatory pain model. The two drugs had similar effects in terms of thermal stimuli. Our lidocaine-based innovative formula represents a novel platform for acquiring topical analgesia. CX001 is safe and more effective than the reference cream for mechanically-induced nociceptive and inflammatory pain.
\end{abstract}

\section{Rezumat}

Analgezicele topice au în continuare probleme de eficacitate, tolerabilitate locală și preț. Scopul studiului este de a evalua eficacitatea unei formule noi bazate pe lidocaină (CX001) în durerea experimentală. Analiza histologică a pielii și țesutului hepatic a fost realizată pentru determinarea siguranței noului compus. CX001 a fost comparat cu EMLA ${ }^{\mathcal{O}}$ (analgezic topic de referință), din punct de vedere al efectului asupra durerii nociceptive şi inflamatorii prin cuantificarea răspunsului șobolanilor la stimuli termici și mecanici. Nu s-au observat modificări cutanate sau hepatice la analiza microscopică. Efectul CX001 a fost superior comparativ cu EMLA ${ }^{\odot}$ din punct de vedere al răspunsului la stimuli mecanici atât pentru durerea nociceptivă cât și pentru cea inflamatorie. Răspunsul la stimuli termici a fost similar. Produsul testat aduce îmbunătăţiri semnificative în administrarea analgezicelor topice. CX001 este sigur și mai eficient decât produsul de referință pentru durerea indusă de stimuli mecanici.

Keywords: CX001, topical analgesic, lidocaine

\section{Introduction}

Pain remains a significant public health concern with a personal and socio-economic impact that is comparable to the one cardiovascular disease and cancer have $[8,19,33]$. Also, pain alters the quality of life, preventing from leading an independent lifestyle, affecting negatively their family, friends and co-workers [3].

Along with physical and emotional influence on patients [1], pain also has a major economic impact, which is either indirect (inability to work) or direct 
FARMACIA, 2019, Vol. 67, 1

(treatment-related costs). In the U.S. alone, the public expenditures for pain related problems ranges between $\$ 560$ and $\$ 635$ billion annually, an amount that equals to about $\$ 2,000$ per person living in the U.S. Also, the total annual costs for pain management are greater than the costs implicated in the management of heart disease ( $\$ 309$ billion), cancer ( $\$ 243$ billion), and diabetes (\$188 billion) [18]. Health practitioners should be trained to correctly administer drugs by harmonization of therapeutics and pharmacology education for a better outcome and compliance in pain therapy $[9,10]$.

As some parts of the world are struggling with the continuous increase in opioids use [5], new solutions in acute and chronic pain management are required. Globally, there is an increase in the number of elderly patients with several comorbidities requiring several types of drugs and thus complex management, which leads to polypragmasia and polypharmacy $[12,38]$. As such, topical analgesics have become a very attractive solution for managing different painful conditions. Topical formulations have local skin delivery, exerting their effects close to the site of application, with a desirable minor systemic uptake and distribution. By using the topical route, the pharmacokinetics of degradable compounds is improved and the frequency of side effects is diminished [35]. Additionally, these drugs are easy to use and monitor, a trait that makes this drug delivery system ideal for certain populations such as the elderly or very young [4].

Currently available topical analgesics contain nonsteroidal anti-inflammatory drugs (NSAIDs) [15], lidocaine, capsaicin, amitriptyline, glyceryl trinitrate, opioids, menthol, pimecrolimus or phenytoin. All have indications in several types of acute or chronic pain [6]. Lidocaine has been used as the main analgesic in several topical products, based on different formulations, different concentrations and various co-analgesics. Topical lidocaine-based commercially available analgesics are presented as patch [28] or cream [41] and literature data indicate that they alleviate several types of acute and chronic pain. However, not all clinical studies agree that current lidocaine formulations are effective. Hashmi et al found that there was no difference between the lidocaine patch and placebo regarding pain reduction in a clinical trial that used both clinical and imaging assessments of pain [23]. Other studies found that topical lidocaine/prilocaine cream has no effect on post-operative pain in women undergoing caesarean section [20] or concluded that there is no significant difference between a lidocaine/prilocaine mixture and applying local pressure over pain intensity after dental injection [29].
Additionally, the response rate for topical applied lidocaine varies greatly throughout studies, types of pain and anatomical site of application, suggesting that although lidocaine is an effective topical analgesic, its formulation still needs improvement. Topical administration of a drug remains a challenge in pharmaceutics [32] because of the difficulties encountered in adjusting the dose to skin penetration by determining and reproducing the exact amount of drug needed for reaching the skin layers at the desired depth [16, 34]. Moreover, since individual drugs have different degrees of penetration, a good formulation is crucial for optimal skin penetration [30].

One other issue specific to low- and middle-income countries is the price and availability of topical analgesics [14]. Most of the existing products are relatively expensive, which is a very important issue if we take into account that the ones that need these drugs (the elderly and/or the ones with several different comorbidities) are the ones than cannot afford it [2]. As such, less expensive products, manufactured locally, are very desirable.

The aim of this study was to assess the efficacy of an innovative lidocaine-based spray on nociceptive and inflammatory experimental pain.

\section{Materials and Methods}

Animals

Adult Balb/c mice $(25 \pm 2 \mathrm{~g})$ were purchased from the Animal Source Unit, Bucharest and were used for toxicity assessment. Adult male Wistar rats (180 - $200 \mathrm{~g}$ ) were purchased from the Animal Source Unit, Bucharest and were used for efficacy assessment. All animals were housed at $21 \pm 2{ }^{\circ} \mathrm{C}$ under a 12-h light/dark cycle with access to food and water ad libitum. Prior to each experiment, animals were habituated to the testing room and the equipment for five consecutive days. The number of animals and intensities of noxious stimuli used were the minimum necessary to demonstrate the consistent effects of the drug treatments.

Ethics statement

The study was conducted in accordance with the 2010/63/EU directive and followed the recommendations of the NIH Guide for the Care and the Use of Laboratory Animals. Prior to the beginning of the study, the protocol received the ethical approval from the ethics committee of the University of Medicine and Pharmacy "Gr. T. Popa", Iaşi.

Drugs

The following drugs were used in the experiment: CX001 was synthesized by "Petru Poni" Institute and $\mathrm{AB}$ Pharm Romania. The formula was delivered as a powder and diluted in saline solution in order to create a spray that was applied by means 
FARMACIA, 2019, Vol. 67, 1

of a commercially-available disperser. CX001 is a matrix-like compound that contains a mixture of innovative polymers and lidocaine. The manner in which lidocaine is included in this compound significantly influences the skin-compound interaction and enhances topical drug diffusion. CX001 aims to surpass the existing topical lidocaine-based analgesics by increasing lidocaine solubility and skin permeability, improving target control and decreasing side-effects and toxicity.

$E M L A^{\odot}$ cream (lidocaine $2.5 \%$ and prilocaine $2.5 \%$ ) (Astra Zeneca) was purchased and used as a reference drug for the efficacy of CX001.

$\lambda$-carrageenan $(C G)$ diluted in fresh saline solution (Sigma- Adrich Germany) was administered subcutaneously in order to produce the model of inflammation.

\section{Tests}

The Hot Plate (HP) test was performed according to the method described by Woolfe and MacDonald with some minor modifications [37]. The rats were individually placed on a hot plate maintained at $55^{\circ} \mathrm{C}\left( \pm 0.1^{\circ} \mathrm{C}\right)$ (Hot Plate Ugo Basile, DS 37, Italy) and the time elapsed before the first sign of discomfort (licking, shaking of hind paws or jumping off the surface) was measured - paw withdrawal latency (PWL). Cut-off time was set at 12 s to prevent tissue damage.

The Cold Plate (CP) test was performed according to the method described by Wal et al with some minor modifications [39]. Briefly, the animals are placed on a $5^{\circ} \mathrm{C}$ thermostatically-maintained plate (Ugo Basile Cold Plate 35100) and the discomfortrelated behaviour in five minutes is quantified. The results were expressed as the number of movements per 300 seconds.

The Randall-Selitto Method was used for assessing the response to mechanical stimuli. The AnalgesyMeter (7200; Ugo Basile, Italy) progressively applies a force that increases by 16 grams/second; the animal's paw is placed on a small plinth under a cone-shaped pusher with a rounded tip. Paw withdrawal occurs when the pressure becomes painful for the animal. The time elapsed until withdrawal was recorded [25].Cut-off time was set at $320 \mathrm{~g}$ (20 seconds).

\section{Carrageenan-induced inflammation}

For assessing the effect of the novel topical analgesic on inflammatory pain, $100 \mu \mathrm{L}$ of $1 \% \lambda$ carrageenan were subcutaneously administered in the ventral aspect of the right hind paw of rats [41]. After injection, the animals were immediately placed in acrylic boxes for observation. The local inflammatory status was monitored by periodic comparison of the two paws (with and without $\lambda$ carrageenan). Inflammation was considered at its peak approximately two hours and forty minutes after injection.
Study design

Safety assessment

Adult male BALB/c mice $(25 \pm 2 \mathrm{~g})$ were divided into six groups ( $n=6 /$ group). Three of the groups received topical administration of EMLA $^{\circledR}, \mathrm{CX}$ or saline solution on the right hind paw. The other three groups first received a subcutaneous injection of $\lambda$-carrageenan into the right hind paw and topical application of $\mathrm{EMLA}^{\odot}, \mathrm{CX}$ or saline 2 hours and forty minutes after. The mice were sacrificed 15 minutes after the topical applications and the liver and the skin of the hind paw were removed and fixed in a $10 \%$ formalin solution for additional tests. Liver samples were stained with the hematoxylin and eosin (HE) coloration. The skin samples were stained with both hematoxylin and eosin (HE) and Szekely tricromic coloration (SZ). All samples were observed microscopically for any histopathological changes.

Nociceptive pain assessment

Rats were divided in three groups ( $n=6$ /group) and each group received as follows: 1. topical administration of a thin layer of EMLA $^{(}$cream (group En), 2. two puffs of saline solution (group $\mathrm{Sn}$ ) and 3. two puffs of CX001 spray (group CXn). HP and Randall-Selitto assessments were performed at baseline and 5, 15, 30, 45, 60, 120, 180 and respectively 240 minutes after administration. The response to cold stimuli was assessed by means of the CP test that was performed at baseline, 30 minutes after topical administration and hourly after that over a four hours period of time.

\section{Inflammatory pain assessment}

All rats were tested by means of HP, CP and Randall-Selitto method at baseline. Afterwards, each animal received a subcutaneous intraplantar injection of $10 \mu \mathrm{L} 1 \% \lambda$-carrageenan into the right hind paw. Two hours and forty minutes after intraplantar administration, rats were divided into three groups ( $n=6 /$ group) receiving either EMLA ${ }^{\circ}$ (group Ei), saline solution (group $\mathrm{Si}$ ) or CX001 (group CXi). HP, CP and the Randall-Selitto assessments were performed with the same frequency as for the nociceptive pain assessment.

Data analysis

Data are expressed as mean \pm SEM. The statistical assessment was performed by means of SPSS v.20 and GraphPad Prism 6.0 software. ANOVA was used to assess time and substance effect. Post-hoc comparisons were performed by using Tukey`s test. The significance level was set a priori at $\mathrm{p}<0.05$.

\section{Results and Discussion}

Safety of the CX001 topical analgesic

Skin tissue from the mice that had only received EMLA $^{\odot} / \mathrm{CX} 001 /$ saline topical application had a normal histological profile. The epidermal, 
superficial dermal and profound dermal layers were in physiological condition. No other differences were noted between groups.

The skin tissue from the mice that had received a subcutaneous carrageenan injection prior to topical drug administration had histological signs of inflammation, with neutrophil infiltration, vascular congestion and oedema (Figure 1). No differences were noted between EMLA ${ }^{\odot}$ and CX001-treated groups, although lidocaine in topical administration (in either EMLA ${ }^{\odot}$ or CX001 formula) was associated with less inflammation.

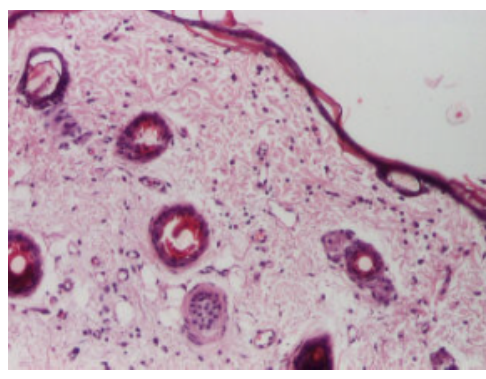

A

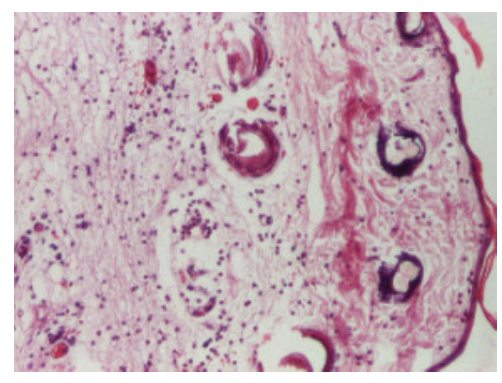

B

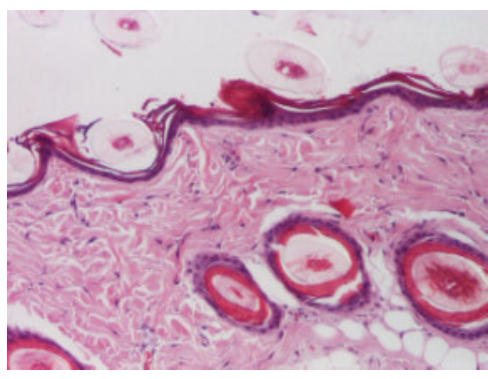

$\mathrm{C}$

Figure 1.

HE coloration - microscopy (x 100) assessment of skin tissue in the inflammation groups. A - EMLA ${ }^{\odot}, \mathrm{B}-$ CX001, C - saline solution

Lidocaine acts as a non-selective $\mathrm{Na}^{+}$channel blocker. Additionally, some studies have shown that the analgesic effect of lidocaine is also due to its interaction with resident cells (keratinocytes and immune), which leads to an anti-inflammatory effect [11]. This effect could account for the results we have obtained in rats with induced inflammation - i.e. less inflammatory cells in EMLA $^{\circledR}$ and CX001-treated groups.

Histological analysis of liver tissue showed that no changes occurred in the hepatic structures. Our results are consistent with preclinical data from other lidocaine formulations [26, 31] and align with other preclinical data we have previously obtained in our laboratory by encapsulating analgesics in similar manners $[13,24]$. The new CX001 compound is an innovative compound with good pre-clinical characteristics regarding both safety and efficacy.

Hot Plate
For the nociceptive pain group, there were no significant differences at baseline, with an average PWL of $3.35 \pm 0.28 \mathrm{~s}$ in the Sn group, $3.48 \pm 0.37 \mathrm{~s}$ in the En group and $3.48 \pm 0.27 \mathrm{~s}$ in the CXn group. Five minutes after topical analgesic/saline administration, EMLA $^{\odot}$ treated animals had an increase in PWL when compared with saline solution $(5.01 \pm 0.47 \mathrm{~s}$ vs. $3.43 \pm 0.22 \mathrm{~s})$ or $\mathrm{CX} 001$ treated animals $(5.01 \pm 0.47 \mathrm{~s}$ vs. $3.16 \pm 0.29 \mathrm{~s})$. PWLs started to increase in the CX001 treated group after this time point and both drugs were superior to saline solution, 15 minutes after administration. The effect remained consistent at 30,45 and 60 minutes after administration ( $p<$ 0.005) (Figure 2). PWLs in all groups were similar at the end of the experiment (after four hours). ANOVA repeated measures identified that there is a significant effect throughout the experiment, with $\mathrm{p}=0.0058(\mathrm{~F}(2,10)=9.022)$ and significance in time $(\mathrm{p}=0.0095)$.

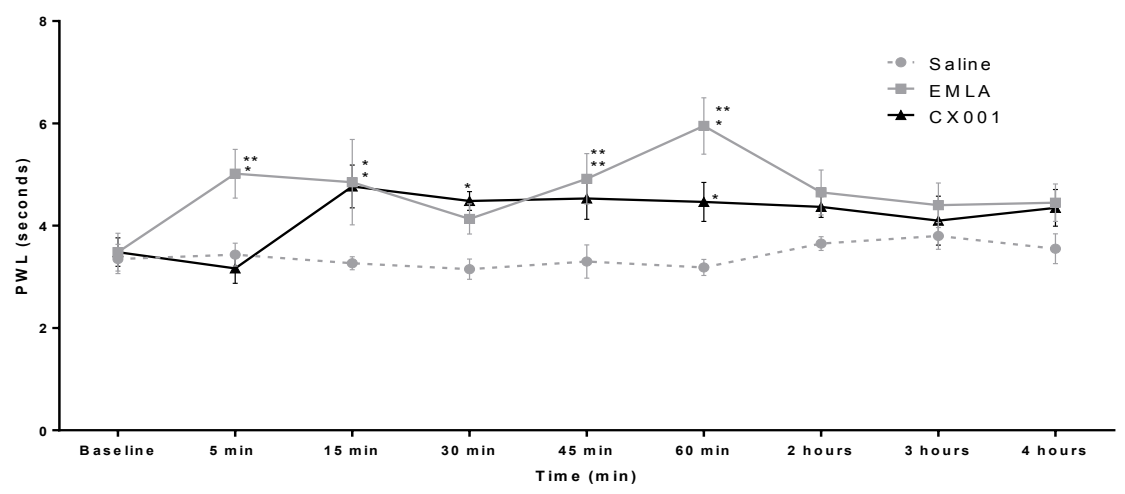

Figure 2.

Hot Plate PWLs in the nociceptive pain group. $*=<0.005$ versus control group; $* *=<0.005$ versus EMLA $^{\circ} / \mathrm{CX} 001$ group 
In the inflammatory pain group, there were also no significant differences between groups at baseline. After CG injection, all animals showed signs of discomfort, avoiding placing the injected hind paw on the ground and licking/scratching the affected area.

Five minutes after topical analgesic/saline administration, saline-treated animals had a lower PWL compared to baseline $(2.66 \pm 0.40 \mathrm{~s})$, whereas $\mathrm{CXi}$ and Ei groups showed no such modifications. Additionally, there was a statistically significant difference between the $\mathrm{Si}$ and $\mathrm{CXi}$ groups ( $\mathrm{p}$
$=0.05)$, but no significant difference between the $\mathrm{Si}$ and Ei groups (Figure 3).

Throughout the experiment, both CX001 and EMLA $^{\odot}$ topical administration led to increased PWLs as compared to saline administration. ANOVA repeated measures identified that there is a significant effect throughout the experiment, with $\mathrm{p}<0.0001(\mathrm{~F}(2,10)=26.86)$ with significance in time $(\mathrm{p}=0.0097)$. There were no significant differences between Ei and CXi groups at any time point.

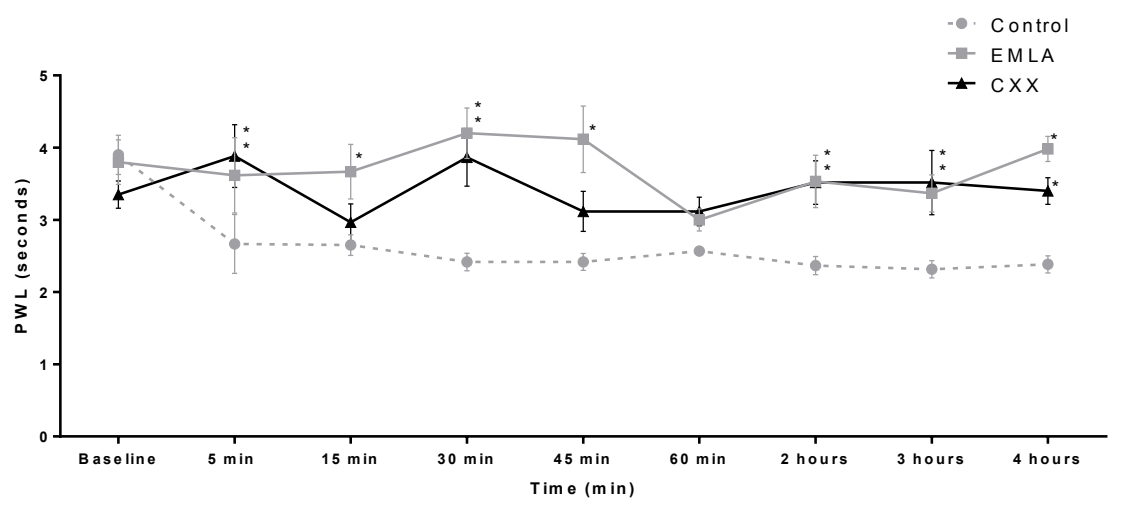

Figure 3.

Hot Plate PWLs in the inflammatory pain group. $*=<0.005$ versus control group; $* *=<0.005$ versus EMLA $^{\oplus} / \mathrm{CX} 001$ group

The Hot Plate test assesses both spinal and supraspinal response, and is widely used in assessing both nociceptive and inflammatory pain [21].

Lidocaine is known to increase Hot Plate latency in several forms of administration and formulation [17], so our results are in line with available data.

CX001 and EMLA $\subset$ have similar efficacy in terms of Hot Plate PWLs, only CX001 becomes effective approximately 15 minutes after EMLA $^{\circledR}$, most likely due to the fact that it is liquid and it only contains lidocaine, not a combination between lidocaine and prilocaine.

\section{Cold Plate}

Regarding nociceptive pain response, neither EMLA $^{\odot}$ nor CX001 induced any significant changes throughout the experiment in the number of cold-evoked movements in 300 seconds. ANOVA repeated measures indicated there was no significant substance or time effect.

These results are in agreement with previously published studies that assessed the effect of the 5\% lidocaine patch in healthy human volunteers and found that the threshold for heat and cold-induced pain were not changed by lidocaine when administered on tissue without inflammation [40].
In the inflammatory pain group, there were no significant differences between groups at baseline, with an average number of cold-evoked movements of $8.75 \pm 0.47 \mathrm{~s}$ in the $\mathrm{Si}$ group, $7.75 \pm 0.48 \mathrm{~s}$ in the Ei group and $7.75 \pm 0.47 \mathrm{~s}$ in the CXi group. Thirty minutes after topical analgesic/saline solution administration, saline treated animals expressed more cold/pressure related discomfort, with an average of $36 \pm 1.58 \mathrm{~s}$ movements in 300 seconds, whereas rats in the $\mathrm{Ei}$ and $\mathrm{CXi}$ groups had an average of $22 \pm 2.27 \mathrm{~s}$ respectively $19.75 \pm 2.05 \mathrm{~s}$ movements (Figure 4).

Throughout the experiment, both CX001 and EMLA $^{\odot}$ topical administration were associated with fewer discomfort related movements as compared with saline administration ( $p<0.005$ for $\mathrm{CXi}$ and $\mathrm{Ei}$ at 30,60 and 120 minutes).

ANOVA repeated measures identified that there is a significant effect throughout the experiment, with $\mathrm{p}=0.04(\mathrm{~F}(2,6)=5.756)$ and that the effect is significant in time $(p=0.0076)$. There were no statistically significant differences between Ei and CXi groups at any time point. 


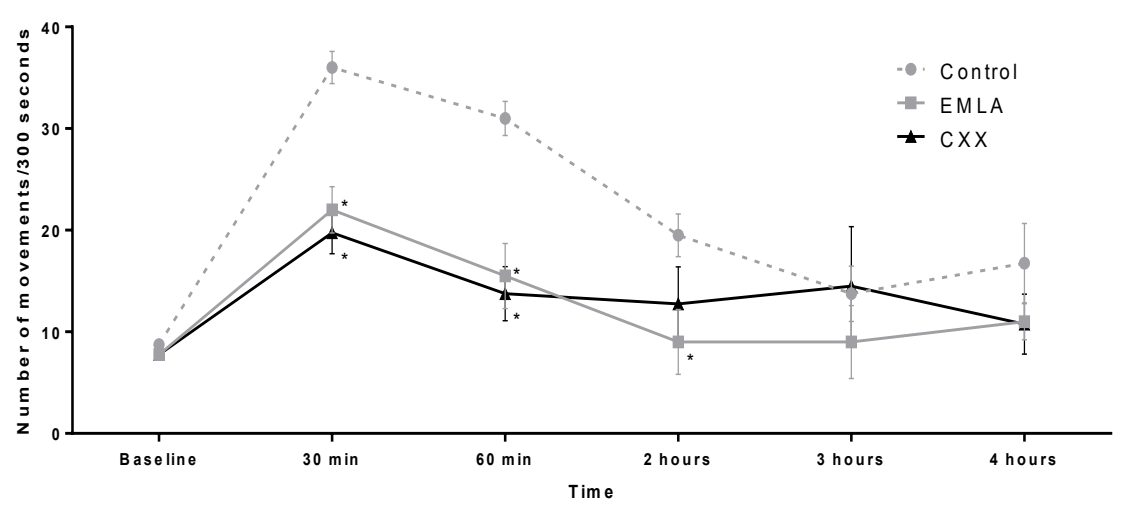

Figure 4.

Hot Plate PWLs in the inflammatory pain group. $*=<0.005$ versus control group; $* *=<0.005$ versus EMLA $^{\odot} / \mathrm{CX} 001$ group

Both EMLA $^{\odot}$ and CX001 were more effective in decreasing the number of cold induced discomfort movements in the inflammatory model than in the nociceptive model. Also, we noted a difference between baseline values and post-CG values in the saline group (when compared to the differences noted in other tests). A possible explanation for this result is the fact that cold itself can act as a pain inhibitor by directly influencing the epidermal nervous terminations [7] and by decreasing sensitivity in the inflamed area.

One other explanation for the fact that both EMLA $^{\odot}$ and CX001 are more effective in the inflammatory model is that lidocaine primarily acts on $\mathrm{A} \delta$ and $\mathrm{C}$ fibers that have abnormal excitation, a situation that occurs in both inflammatory and neuropathic pain [23].

The Randall-Selitto Method
Regarding the nociceptive pain response, there were no significant differences between groups at baseline, with an average PWL of $6.66 \pm 0.49 \mathrm{~s}$ in the $\mathrm{Sn}$ group, $7.33 \pm 0.66 \mathrm{~s}$ in the En group and $6.33 \pm 0.62 \mathrm{~s}$ in the CXn group. Five minutes after topical application, the EMLA $^{\odot}$-treated group had significantly increased PWLs, with an average of $13.58 \pm 2.43 \mathrm{~s}$ when compared with CXn $(8.00 \pm$ $1.01 \mathrm{~s})$ and $\mathrm{Sn}(7.00 \pm 0.85 \mathrm{~s})$ groups. CX001treated animals, however, experienced a slow progressive increase in PWL and surpassed the PWLs of the EMLA $^{\odot}$ group at 30 and 45 minutes (Figure 5). One hour after administration, all groups had PWLs similar to those at baseline, a result that was consistent over the two, three and four hour assessments. ANOVA repeated measures identified that there is a significant effect with $\mathrm{p}=0.008$ and $\mathrm{F}(16,80)=2.279$.

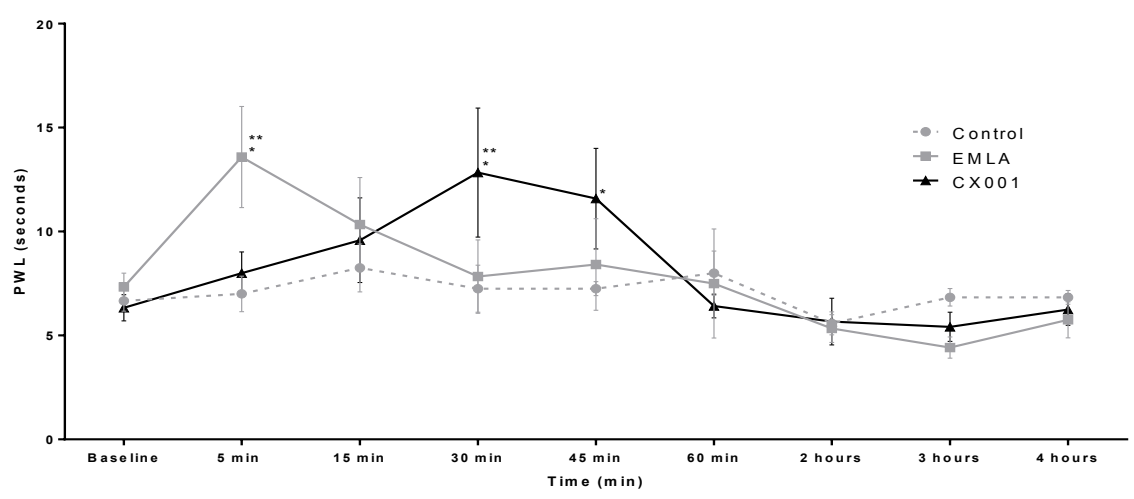

Figure 5.

Mechanical PWLs in the nociceptive pain group. $*=<0.005$ versus control group; $* *=<0.005$ versus EMLA $^{\odot} / \mathrm{CX} 001$ group

In the inflammatory pain group, there were also no significant differences between groups at baseline, with an average PWL of $8.33 \pm 1.08 \mathrm{~s}$ in the $\mathrm{Si}$ group, $7.08 \pm 0.68 \mathrm{~s}$ in the Ei group and $8.33 \pm 0.92$ $\mathrm{s}$ in the $\mathrm{CXi}$ group. Five minutes after
$\mathrm{EMLA}^{\odot} / \mathrm{CX} 001$ topical applications, both formulations led to a statistically significant increase in PWL when compared to saline. Fifteen minutes after topical application, the CXi group had longer PWLs when compared to the Ei group 
FARMACIA, 2019, Vol. 67, 1

$(12.41 \pm 1.72$ s vs. $5.16 \pm 0.45$ s), a significant difference that lasted up to two hours after topical drug administration (Figure 6). ANOVA repeated measures identified that there is a significant effect throughout the experiment, with $\mathrm{p}<0.0001$ (F (2, $10)=93.16)$ and that it is significant in time $(\mathrm{p}<$ 0.0001 ). At the end of the experiment (4 hours after administration), all groups had similar PWLs (4.08 $\pm 0.20 \mathrm{~s}$ in the $\mathrm{Si}$ group, $4.75 \pm 1.17 \mathrm{~s}$ in the Ei group and $6.08 \pm 0.15 \mathrm{~s}$ in the CXi group).

Our results are in concordance with available literature indicating that EMLA $^{\odot}$ topical administration is only slightly effective in reducing tactile sensitivity in newborn rats [36]. A recently published clinical trial showed that EMLA $^{(}$ partially decreases pain during tympanocentesis in less than a third of the patients [27]. The result of this study is particularly relevant, especially since the perinatal period is considered to be a time where topical analgesics are most effective [22]. Due to its improved formula, CX001 is significantly superior to EMLA $^{\odot}$ as assessed by the Randall-Selitto test, a method that primarily evaluates the response to tactical stimuli.

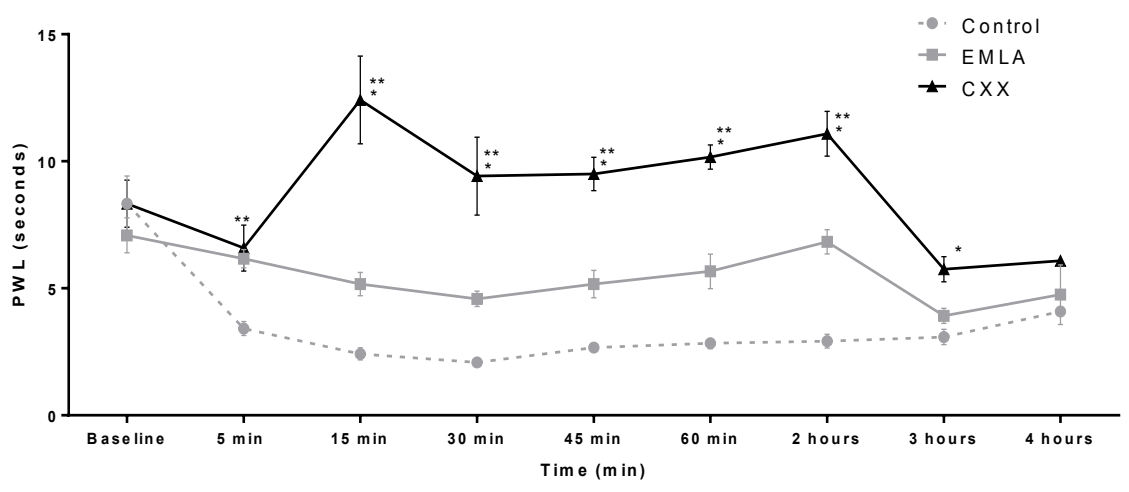

Figure 6.

Mechanical PWLs in the inflammatory pain group. $*=<0.005$ versus control group; $* *=<0.005$ versus EMLA $^{\top} / \mathrm{CX} 001$ group

\section{Conclusions}

The new innovative CX001 lidocaine-based topical formulation is a novel platform for topical drug delivery. CX001 has an excellent safety profile, with no significant site-specific reactions and no hepatic toxicity. CX001 rapidly dissolves in saline in order to create a spray that can be topically administered with ease. The new formula is as effective as the lidocaine $2.5 \%$-prilocaine $2.5 \%$ reference cream in alleviating nociceptive pain and is more effective in pressure-induced inflammatory pain. The obtained results indicate that CX001 has the potential to inhibit pain and may be topically applied for pressure-related pain management.

\section{Acknowledgement}

This study was supported by a grant from the Romanian National Authority for Scientific Research (CNCS - UEFISCDI), project number PN-II-PT-PCCA-2013-4-2210 (NANODERMA). The funders had no role in study design, data collection and analysis, decision to publish, or preparation of the manuscript.

\section{References}

1. Ababei DC, Beschea Chiriac S, Bild W, Solcan C, Luca A, Rusu RN, Bulea D, Bild V, Synergistic effects of the doxepin-candesartan combination on the thermoalgesic sensibility in mice. Farmacia, 2017; 65(5): 726-730.

2. Alexa ID, Ilie A, Morosanu A, Emmanouil-Stamos P, Raiha I, Self-neglect in elders: a world-wide issue ignored in Romania. Rev Rom Bioet., 2012; 10(1): 141-148.

3. Alexa ID, Pancu AG, Moroşanu AI, Ghiciuc CM, Lupuşoru C, Prada GI, Cepoi V, The impact of self-medication with NSAIDs/analgesics in a northeastern region of Romania. Farmacia, 2014; 62(6): 1164-1170.

4. Alexa O, Veliceasa B, Malancea R, Alexa ID, Postoperative cognitive disorder has to be included within informed consent of elderly patients undergoing total hip replacement. Rev Rom Bioet., 2013; 11(4): 38-47.

5. Anitescu M, Benzon HT, Argoff CE, Advances in topical analgesics. Curr Opin Anaesthesiol., 2013; 26(5): 555-561.

6. Argoff CE, Topical analgesics in the management of acute and chronic pain. Mayo Clin Proc., 2013; 88(2): 195-205.

7. Barkin RL, The pharmacology of topical analgesics. Postgrad Med., 2013; 125(1): 7-18.

8. Breivik H, Eisenberg E, O'Brien T, OPENMinds, The individual and societal burden of chronic pain in Europe: the case for strategic prioritisation and action to improve knowledge and availability of appropriate care. BMC Public Health., 2013; 13(1): $1-14$. 
FARMACIA, 2019, Vol. 67, 1

9. Bild V, Ababei DC, Neamtu M, Vasincu A, Bild W, Stanciu GD, Tamba BI, Solcan G, Beschea Chiriac S, Isobolar analysis of the binary fixedratio combination of acetylsalicilic acidacetaminophen. Farmacia, 2017; 65(4): 563-566.

10. Brinkman DJ, Tichelaar J, Schutte T, Benemei S, Bottiger Y, Chamontin B, Christiaens T, Likic R, Maiulaitis R, Marandi T, Monteiro EC, Papaioannidou P, Pers YM, Pontes C, Raskovic A, Regenthal R, Sanz EJ, Tamba BI, Wilson K, de Vries TP, Richir MC, van Agtmae MA, Essential competencies in prescribing: A first European cross-sectional study among 895 final-year medical students. Clin Pharmacol Ther., 2017; 101(2): 281289.

11. Cassuto J, Sinclair R, Bonderovic M, Antiinflammatory properties of local anesthetics and their present and potential clinical implications. Acta Anaesthesiol Scand., 2006; 50(3): 265-282

12. Cepoi V, Alexa ID, Ilie A, Alexa O, Ethical dilemmas in treating elderly patients at risk for polypragmasy and polypharmacy. Rev Rom Bioet., 2014; 12(3): 12-18.

13. David G, Jaba IM, Tamba B, Bohotin C, Neamtu A, Patras X, Simionescu BC, Mungiu OC, Antinociceptive effect of morphiceptin loaded poly(butylcyanoacrylate) nanoparticles. Rev Roum Chim., 2010, 55(11-12): 923-931.

14. De Lima L, Pastrana T, Radbruch L, Wenk R, Cross-sectional pilot study to monitor the availability, dispensed prices, and affordability of opioids around the globe. $J$ Pain Symptom Manage., 2014; 48(4): 649-659.

15. Derry S, Conaghan P, Da Silva JAP, Wiffen PJ, Moore RA, Topical NSAIDs for chronic musculoskeletal pain in adults. In Cochrane Database of Systematic Reviews, ed S Derry. 4:CD007400. Chichester, UK: John Wiley \& Sons, Ltd, 2016.

16. Draganescu D, Ibanescu C, Tamba BI, Andritoiu C V, Dodi G, Popa MI, Flaxseed lignan wound healing formulation: Characterization and in vivo therapeutic evaluation. Int J Biol Macromol., 2015; 72: 614-623.

17. Er BM, Kocamanoglu IS, Bozkurt A, Bilge S, Cetinoglu EC, Evaluation of postoperative antinociceptive efficacy of intrathecal dexketoprofen in rats. Balkan Med J., 2016; 33(3): 245-251.

18. Stanciu GD, Solcan G, Acute idiopathic polyradiculoneuritis concurrent with acquired myasthenia gravis in a West Highland white terrier dog. BMC Veterinary Research, 2016; 12: 1-6.

19. Gavrilovici C, Luca A, Antoniu SA, Gallaby K, Stefanescu R, Starcea M, Miron I, Bild V, How nephrotoxic is the cancer therapy in children? Farmacia, 2018; 66(2): 197-208.

20. Grosse-Steffen T, Krämer M, Tuschy B, Weiss C, Sütterlin M, Berlit S, Topic anaesthesia with a eutectic mixture of lidocaine/prilocaine cream after elective caesarean section: a randomised, placebocontrolled trial. Arch Gynecol Obstet., 2017; 296(4): 771-776.
21. Gunn A, Bobeck EN, Weber C, Morgan MM, The influence of non-nociceptive factors on hot-plate latency in rats. J Pain., 2011; 12(2): 222-227.

22. Hardman MJ, Sisi P, Banbury DN, Byrne C, Patterned acquisition of skin barrier function during development. Development, 1998; 125(8):1541152.

23. Hashmi JA, Baliki MN, Huang L, Parks EL, Chanda ML, Schnitzer T, Apkarian AV, Lidocaine patch $(5 \%)$ is no more potent than placebo in treating chronic back pain when tested in a randomised double blind placebo controlled brain imaging study. Mol Pain, 2012; 8: 1-10.

24. Iurea (Rata) DM, Popa M, Chailan JF, Tamba BI, Tudorancea I, Peptu CA, Ibuprofen-loaded chitosan/poly(maleic anhydride-alt-vinyl acetate) submicronic capsules for pain treatment. $J$ Bioact Compat Polym., 2013; 28(4): 368-384.

25. Jeong HJ, Mitchell VA, Vaughan CW, Role of 5HT(1) receptor subtypes in the modulation of pain and synaptic transmission in rat spinal superficial dorsal horn. Br J Pharmacol., 2012; 165(6): 19561965.

26. Ji Y, Guo L, Zhang Y, Liu Y, Comparison of topical anesthesia and subcutaneous infiltration anesthesia with regard to effect of plasma skin regeneration system. $J$ Cosmet Laser Ther., 2015; 17(6): 330-334.

27. Jyväkorpi M, A comparison of topical EMLA cream with Bonain's solution for anesthesia of the tympanic membrane during tympanocentesis. Eur Arch Otorhinolaryngol, 1996; 253(4-5): 234-236.

28. Mick G, Correa-Illanes G, Topical pain management with the $5 \%$ lidocaine medicated plaster-a review. Curr Med Res Opin., 2012; 28(6): 937-951.

29. Milani AS, Zand V, Abdollahi AA, Froughreyhani M, Zakeri-Milani P, Jafarabadi MA, Effect of topical anesthesia with lidocaine-prilocaine (EMLA) cream and local pressure on pain during infiltration injection for maxillary canines: A randomized double-blind clinical trial. J Contemp Dent Pract., 2016; 17(7): 592-596.

30. Nagai N, Ogata F, Deguchi S, Ueno A, Kawasaki $\mathrm{N}$, Ito $\mathrm{Y}$, Combination ointment containing solid tranilast nanoparticles and dissolved sericin is efficacious for treating skin wound-healing deficits and redness in diabetic rats. Biol Pharm Bull., 2017; 40(4): 444-450.

31. Negi P, Singh B, Sharma G, Beg S, Katare OP, Biocompatible lidocaine and prilocaine loadednanoemulsion system for enhanced percutaneous absorption: QbD-based optimisation, dermatokinetics and in vivo evaluation. $J$ Microencapsul., 2015; 32(5): 419-431.

32. Peptu C, Rotaru R, Ignat L, Humelnicu AC, Harabagiu V, Peptu CA, Leon MM, Mitu F, Cojocaru E, Boca A, Tamba BI, Nanotechnology approaches for pain therapy through transdermal drug delivery. Curr Pharm Des., 2015; 21(42): 6125-6139.

33. Stanciu GD, Armașu M, Musteață M, Solcan G, Evaluation of central vestibular syndrome at dogs using brainstem auditory evoked responses 
recorded with surface electrodes. Arquivo Brasileiro de Medicina Veterinária e Zootecnia, 2016; 68(6): 1422-1430.

34. Santini B, Zanoni I, Marzi R, Cigni C, Bedoni M, Gramatica F, Palugan L, Corsi F, Granucci F, Colombo M, Cream formulation impact on topical administration of engineered colloidal nanoparticles. PLoS One, 2015; 10(5): 1-14.

35. Sawynok J, Topical analgesics for neuropathic pain: Preclinical exploration, clinical validation, future development. Eur J Pain, 2014; 18(4) :465481.

36. Strain MM, Vineyard MA, Roberto ME, Brumley MR, Effectiveness of topical anesthetics on reducing tactile sensitivity in the paws of newborn rats. Dev Psychobiol., 2014; 56(1): 126-132.

37. Tamba BI, Leon M-M, Petreus T, Common trace elements alleviate pain in an experimental mouse model. J Neurosci Res., 2013; 91(4): 554-561.

38. Uritu CM, Mihai CT, Stanciu G, Dodi G, AlexaStratulat T, Luca A, Leon-Constantin MM, Stefanescu R, Bild V, Melnic S, Tamba BI,
Medicinal plants of the family Lamiaceae in pain therapy: A review. Pain Res Manag., 2018; 1-44.

39. van der Wal S, Cornelissen L, Behet M, Vaneker M, Steegers M, Vissers K, Behavior of neuropathic pain in mice following chronic constriction injury comparing silk and catgut ligatures. Springerplus, 2015; 4:1-8.

40. Wehrfritzl A, Namerl B, Ihmsenl H, Muellerl C, Filitzl J, Koppertl W, Lefflerl A, Differential effects on sensory functions and measures of epidermal nerve fiber density after application of a lidocaine patch $(5 \%)$ on healthy human skin. Eur $J$ Pain, 2011; 15(9): 907-912.

41. Wigerblad G, Huie JR, Yin HZ, Leinders M, Pritchard RA, Koehrn FJ, Xiao WH, Bennett GJ, Huganir RL, Ferguson AR, Weiss JH, Svensson CI, Sorkin LS, Inflammation-induced GluA1 trafficking and membrane insertion of $\mathrm{Ca}^{2+}$ permeable AMPA receptors in dorsal horn neurons is dependent on spinal tumor necrosis factor, PI3 kinase and protein kinase A. Exp Neurol., 2017; 293: 144-158. 